\title{
DISCLAIMER
}

This report was prepared as an account of work sponsored by an agency of the United States Government. Neither the United States Government nor any agency thereof, nor any of their employees, makes any warranty, express or implied, or assumes any legal liability or responsibility for the accuracy, completeness, or usefulness of any information, apparatus, product, or process disclosed, or represents that its use would not infringe privately owned rights. Reference herein to any specific commercial product, process, or service by trade name, trademark, manufacturer, or otherwise does not necessarily constitute or imply its endorsement, recommendation, or favoring by the United States Government or any agency thereof. The views and opinions of authors expressed herein in not necessarily state or reflect those of the United States Government or any agency the. $\boldsymbol{N}$.
EGG-LLW- $-9343-$ ReV. 1

DE9 10061.48

\section{Approaches to LLW Disposal Site Selection and Current Progress of Host States}

John J. Walsh

Thomas A. Kerr

November 1990

EG\&G Idaho, Inc.

Idaho Falls, Idaho 83415

\author{
Prepared for the \\ U.S. Department of Energy \\ Idaho Operations office \\ Under DCE Contract No. DE-ACO7-76ID01570
}




\section{ABSTRACT}

In accordance with the Low-Level Radioactive Waste Policy Amendments Act of 1985 and under the guidance of 10 CFR 61, States have begun entering into compacts to establish and operate regional disposal facilities for low-level radioactive waste. The progress a State makes in implementing a process to identify a specific location for a disposal site is one indication of the level of a State's commitment to meeting its responsibilities under Federal law and interstate compact agreements. During the past few years, several States have been engaged in site selection processes. The purpose of this report is to summarize the site selection approaches of some of the Host States (California, Michigan, Nebraska, New York, North Carolina, Texas, and Illinois), and their progress to date. An additional purpose of the report is to discern whether the Host States' site selection processes were heavily influenzed by any common factors. One factor each State held in common was that political and public processes exerted a powerful influence on the site seiection process at virtually every stage. 
CONTENTS

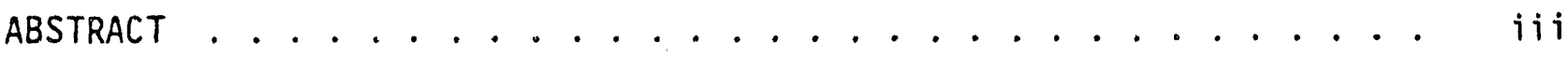

INTRODUCTION . . . . . . . . . . . . . . . . . . . . . . 1

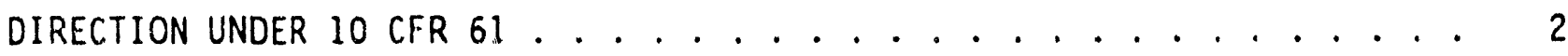

HOST STATE APPROACHES . . . . . . . . . . . . . . . . . . 4

California--Host State for the Southwest Compact Region ...... 4

Michigan--Host State for the Midwest Compact Region . . . . . . . 8

Nebraska--Host State for the Central Compact Region . . . . . . 13

New York ........................ . . 17

North Carolina--Host State for the Southeast Compact Region . . . . 24

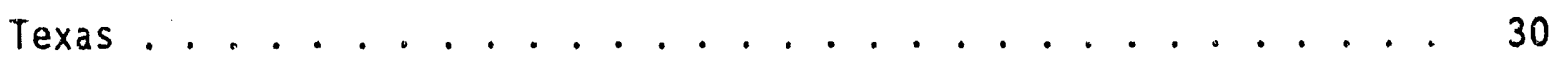

Illinois--Host State for the Central Midwest Compact Region . . . . 36

CONCLUSION . . . . . . . . . . . . . . . . . . . . . 4 42

REFERENCES .......................... . . . 44 


\title{
APPROACHES TO LLW DISPOSAL SITE SELECTION AND CURRENT PROGRESS OF HOST STATES
}

\author{
INTRODUCTION
}

In 1959, States began assuming responsibility for 1 icensing and regulating radioactive waste and other materials following enactment of an amendment to the Atomic Energy Act of 1954. States which entered into an agreement with the U.S. Nuclear Regulatory Commission to regulate certain types of radioactive materials (including low-level radioactive waste) were known as Agreement States. The Low-Level Radioactive Waste Policy Amandments Act of 1985 (the Act) reaffirms policies of earlier legislation making States responsible for disposal of certain low-level radioactive waste (LLW) generated within their borders. A Host State is a State which is responsible for developing a LLW disposal facility either on its own or for a compact region of States.

In agreement with the earlier Low-Level Radioactive Waste Policy Act of 1980, the Act found that low-level radioactive waste can be disposed of most safely and effectively on a regional basis. The Act provided that states may enter into compacts to establish and operate regional disposal facilities for low-level radioactive waste. The Act also provided that $L L W$ compact regions given Congressional ... nsent could limit use of their disposal sites to waste generated within their respective regions. The Act sets forth a series of milestones, incentives, and penalties for development of new LLW disposal capacity. Compact regions and States that meet each of the milestones may continue to access the three operating disposal facilities in Nevada, South Carolina, and Washington through 1992.

The progress a State makes in implementing a process to identify a specific location for a LLW disposal site is one indication of the level of a State's commitment to meeting its responsibilities under Federal law and interstate compact agreements. During the past few years, several Host States have been engaged in site selection processes. This report summarizes their approaches to site selection and their progress thus far. 


\section{DIRECTION UNDER 10 CFR 61}

The U.S. Nuclear Regulatory Commission (NRC) defines the technical and procedural framework for site selection in Title 10, Code of Federal Regulations, Part $61^{\prime}$ (10 CFR 61). This regulation outlines the procedures, criteria, and conditions under which the NRC or an Agreement State agency will review applications and issue a license for the disposal of low-level radioactive waste. The regulation defines the performance objectives and technical requirements that must be met throughout the life of the disposal facility.

10 CFR 61 establishes four performance objectives for a disposal facility: - The facility must provide reasonable assurances that the general
population will ve protected from the release of radioactivity
- During the postclosure period, inadvertent intruders onto the site will not be exposed to unacceptable levels of radioactivity
- Individuals operating the facility must have adequate protection from radiation exposure
- The disposal sit must remain stable during the postclosure period.

The regulation also sets forth a number of technical requirements. These address

- Disposal site suitability requirements

- Disposal site design

- Disposal facility operation and closure

- Environmental monitoring

- Alternative requirements for design and operations

- Waste classification

- Waste characteristics

- Labeling 
- Alternative requirements for waste classification and characteristics

- Institutional requirements.

In addition to the general requirements in 10 CFR 61, each State has established siting requirements specific to its particular needs and circumstances. These include hydrological and geological factors, environmental and public health factors, natural and cultural resource factors, socioeconomic factors, local land use factors, transportation factors, and aesthetic factors.

States have flexibility in the approaches they use in selecting disposal sites. Generally, a geographic map overlay process is used to eliminate large tracts of land from further consideration or to identify locations that may be suitable for a disposal site. For purposes of efficiency, site screening generally uses a phased approach, first applying data which is readily and uniformly available across the entire study area. By first eliminating areas easily identifiable as not suitable, subsequent phases of the screening can focus on smaller land units for which data may be more difficult to attain. After exhausting all available data that can be applied in a map screening process, area visits by teams of specialists are generally necessary in order to identify local features that qualify or disqualify specific areas.

Two kinds of criteria generally are used in screening: exclusionary and avoidance (the names may vary). Areas that include exclusionary factors are eliminated from further consideration. The effect of avoidance criteria on an area is cumulative, so that an area may be eliminated if it exhibits a number of avoidance characteristics. Some States use formulas that assign each avoidance criteria a numerical value based on its importance to the screening process while other States do not use these "weighting factors." Screening may also be conducted using "favorability" criteria to identify eligible areas, rather than using avoidance criteria to eliminate ineligible areas. Because favorability criteria are the converse of avoidance criteria, the practical effect on site identification is the same. 
The varying approaches taken by States result from differing prescriptions in State siting laws, different ways to apply the general requirements of 10 CFR 61 , and different methodologies used by States in the site selection process.

\section{HOST STATE APPROACHES}

Following is a description of the methods and criteria used by some of the States that have undertaken the siting process. These are California, Michigan, Nebraska, New York, North Carolina, Texas, and Illinois.

\section{California--Host State for the Southwest Compact Region}

California is the Host State for the Southwestern Low-Level Radioactive Waste Disposal Compact region, which also includes Arizona, North Dakota, and South Dakota. Under the compact legislation, California will be Host State for the LLW disposal facility for 30 years and has the option of extending its duration as Host State. The State expects the disposal facility to become operational in late 1991. The compact legislation leaves the responsibility for establishing and regulating the disposal facility to the Host State.

In 1983, prior to California's membership in a compact region, the State enacted a Senate bill requiring California to develop a LLW disposal facility in response to the requirements of the Federal Low-Level Radioactive Waste Policy Act of 1980. The California law directed the Department of Health Services (DHS) to conduct a screening study to identify potentially suitable siting areas within the State, and to select a license designee from the private sector to establish a disposal facility.

The regional screening was based on criteria established in 10 CFR 61 , as well as on additional State exclusionary and suitability criteria developed in 1982. Under State screening criteria, a disposal facility

- Must be located away from large, expanding population centers

- Must be located where 10 inches of rain or less falls annually 
- Should not be located in areas where facility operations may degrade groundwater quality

- Should not be over zones of active faulting where seismic activity could affect the facility's operations and objectives

- Should not be within an area with conditions that will be conducive to flooding, in a coastal high hazard area, wetlands or 100-year flood plain

- Should have features to allow full characterization, modeling, monitoring, and analysis of geologic, meteorologic, hydrologic, and radiologic factors.

The DHS completed its screening in April 1984. The requirement 1 imiting the amount of rainfall eliminated large portions of the State and led DHS to designate the State's arid regiors as potentially eligible for the site at this first level of screening.

The 1983 California law requires the DHS to select a company from the private sector to be license designee with the eiclusive right to find a site, apply for a license, develop a disposal facility, operate it, and eventually close it. The law, however, does not make a State agency responsible for overseeing the progress of site development activities.

During 1984, US Ecology submitted a proposal to site, build, and operate a LLW disposal facility in California. In its proposal, the company expanded the State siting criteria and developed the concept of siting a disposal facility in topographically closed desert basins, on the premise that sites in such basins could be characterized and modeled with a greater degree of confidence than other locations. Fourteen desert basins in California's southeastern desert were identified as preliminary study areas in the bid propusal.

US Ecology was selected in December 1985 and given the authority to identify and evaluate potential siting areas; select the site; apply for a license; and develop, operate and eventually close a disposal facility. Early in 1986, the company reviewed the 14 proposed preliminary basin areas against Federal and State criteria and expanded the preliminary areas to 18 areas 
located in Inyo, Riverside, and San Bernardino counties. Further evaluation using exclusicnary and high-avoidance criteria reduced the areas to 16 basins comprising slightly more than 1,000 square miles.

State legislation required public involvement in the siting process. In the contract proposal, US Ecology noted that it considered public involvement in the siting process to be a key element in public acceptance of the final decision. US Ecology sponsored the League of Women Voters in establishing a citizens' advisory committee (CAC) to participate with the company in developing site selection criteria, assigning relative weights and values to thos: criteria, evaluating attributes of specific siting areas, and recommending specific siting areas for detailed study.

The CAC was composed of 12 members: three from each of the three counties containing the basins, one Native American representative, one. at-large environmental group representative, and one representative from the low-level radioactive waste generators.

The CAC met six times from June 1986 through January 1987, and progressed through a series of steps before recommending to US Ecology a set of preferred siting areas. During this series of meetings, the CAC helped US Ecology identify areas of public concern in selecting a disposal site, helped establish siting criteria, and rated each of the 16 candidate sites.

Based on field reconnaissance, CAC recommendations, public meeting comments, citizen letters, resolutions from local officials, and consultation with Native American tribal groups, in February 1987 US Ecology designated three areas for detailed site characterization: Ward Valley, Silurian Valley, and Panamint Valley.

Initially, each of the three candidate sites received equal emphasis. characterization included evaluation of mineral resource management, well canvasses, electrical resistivity sounding, gravity and magnetic surveys, seismic work and surface water flow stuaies. These were intended to identify factors that would disqualify the sites from receiving an operating license. 
Exploratory borings and groundwater table observation wells were planned for each site. However, seismic profiles for the Panamint Valley site indicated the possible presence of earthquake faults underlying the site. Drilling was deferred there, and wells and meteorological stations were developed only for the Ward and Silurian sites.

US Ecology continued public involvement, working with the League of Women Voters to establish a local advisory committee for each site. The local committees, whose members were nominated by local organizations, served as objective fact-finding organizations. They provided US Ecology with community views on issues important to the siting process and helped make information about the project available to the comnunity.

Comprehensive descriptions of each candidate site were sent to CAC members in September 1987, with the request that the members compare the three sites and recommend which sites should be proposed for development and which, if any, should be eliminated from consideration. The CAC unanimouily recommended that the Panamint Valley site be removed from consideration. The group was divided on which of the remaining two sites was preferred.

Both the Ward and Silurian Valley sites satisfied US Ecology's criteria of a technically excellent site that was also generally supported by the local community. However, from the technical factors related to licensing, US Ecology believed the Ward Valley site was the better location. Contributing factors included superior surface water and erosion control conditions, greater depth to groundwater and bedrock, greater distance to active and potentially active earthquake faults, and superior infiltration resistance characteristics. Biologically, however, development of the Ward Valley site colild have a greater environmental impact because of its location in desert tortoise habitat and because it is in an area of greater overall biological diversity.

An ad hoc Desert Tortoise Working Group was formed to study the impact the disposal facility might have on the tortoise. The group recommended, among other measures, fencing the disposal site, relocating tortoises within 
their existing home range, and educating site workers about the reptile. The working group also had determined that tortoises were being killed while crossing a rearby highway. The group recommended fencing along that portion of the highway traversing the desert tortoise home range, forcing the tortoises to use existing culverts under the highway to get from one side of the road to the other. If such measures were implemented, it was believed that development of the site in Ward Valley could result in a net benefit to the species.

The Ward Valley site was designated as the proposed site in March 1988 by US Ecology and was accepted by the DHS. A license application was submitted to the OHS in December 1989. License application hearings were held in three locations in the desert area of southwestern California July 16, 17, and 18, 1990. No issues arose that could cause undue delay in the siting process. US Ecology will continue working on the environmental impact report and the license review documents. DHS certification of the environmental impact report is expected by the fall of 1990 and a licensing decision by the end of the year. The facility is expected to be operational in 1ate 1991, well in advance of the January 1, 1593, deadline.

\section{Michigan--Host State for the Midwest Compact Region}

Michigan enacted legislation in 1982 authorizing the State to enter the Midwest Interstate Low-Le' ol Radioactive Waste Management Compact. The compact region also includes Indiana, Iowa, Minnesota, Missouri, Ohio, and Wisconsin. In June 1987, the compact region member States selected Michigan to be the initial Host State for the compact region's LLW disposal facility.

In December 1987, the Michigan Low-Level Radioactive Waste Authority (the Authority) was established by State law and was given responsibility to implement the State program to develop a low-level radioactive waste disposal facility. Specific responsibilities include developing a siting process, identifying siting criteria, selecting a site for recommendation to the state legislature for approval, and applying for a license to develop and operate the facility. 
The Authority established a siting criteria advisory committee, as mandated by law, to assist the Authority in carrying out its responsibilities. The advisory committee, made up of five technical members from the Michigan Technological University, Michigan State University, and the University of Michigan, assisted the Authority in establishing siting criteria. The criteria adopted by the Authority are based on Federal regulations, including 10 CFR 61 as well as applicable Michigan statutes. Michigan's siting criteria are divided into two categories: exclusionary criteria that eliminate an area from further consideration, and favorability criteria that distinguish the relative suitability of those areas not excluded from further consideration.

The siting process established by the Authority involves

- Conducting a statewide exclusionary screening to identify the remaining potentially suitable areas

- Screening the potentially suitable areas to identify candidate areas

- Selecting three candidate sites for site characterization

- Evaluating the candidate sites to select a preferred host site for recommendation to the State legislature for consideration.

Between November 1988 and September 1989, a team of Michigan State University scientists applied statewide criteria to eliminate areas from further consideration. The team divided the State into individual geographic cells each measuring one square kilometer. Using an automated system, each square was compared against certain of the exclusionary criteria; if a square met any of the criteria, it was removed from consideration.

Excluded were incorporated areas and urban population centers, areas adjacent to major water bodies subject to flooding, areas subject to geologic instability, and areas located within 10 miles of the Great Lakes. Also excluded were unique wilderness areas, national and State parks, and wild and scenic rivers.

Application of exclusionary criteria eliminated 97 percent of the State 
from further considerizion, leaving three percent or 1,127,000 acres of Michigan 1 and (81 contiguous areas) as potentially suitable for a disposal facility.

In October 1989, the Authority announced selection of three candidate areas contained entireiy within the borders of three counties. The three areas totalied 49,000 acres, or one-tenth of one percent of the State. The candidate areas were 16,550 acres in St. Clair County, 16,750 acres in Ontonagan County, and 15,500 acres in Lenawee County.

The Authority sele ted the three areas because they were the largest contiguous areas among those identified as potentially suitable in the exclusionary screening. The large areas were selected in order to give the Authority flexibility in identifying three candidate sites of 2,250 to 4,000 acres. The site sfecifisation of 2,250 acres corresponds to the minimum parcel capable of being analyzed using the computer mapping system available to the Authority and the minimum size necessary to allow flexibility in the final placement of a 1,200-acre facilit.., the size specified in Michigan law. (For comparison, the Barnwell County disposal site in South Carolina, currently the nation's largest, is just over 200 acres, including all buffer zones and administrative areas.)

The Authority established a public advisory committee to assist and advise the Authority on the evaluation of the three candidate areas. The public advisorj committee is made up of representatives chosen from organizations recognized for skills and expertise in different subjects important to siting a disposal facility. Chaired by the representative of the League of yomen Voiers, the committee includes members from the Farm Bureau; the Archaeological Society; the Commission on Indian Affairs; the State Chamber of Comrierce; the Groundwater Survey; the Nature Conservancy; the Folkiore Society; the Academy of Science, Arts and Letters; and the lip of the Mitt Watershed Council. The committee provides the Authority with independent expert advice and ensures that evaluations of potential resource impacts are as complete as possible. Although the committee has no voting authority or responsibility to make a site recommendation, each organization member will 
prepare his or her own section only of the report to be presented to the Authority for consideration in the candidate area evaluations.

Upon identifying three candidate sites, Michigan law directs the Authority to establish local monitoring cominittees in each of the candidate site communities, with commitiee members appointed by community officiais. Each monitoring committee will independently review the data gathered for its specific site and make recommendations to the Autho. ' $\pm y$ on ways to address pubiic concerns regarding the siting process. The Auchority will provide annual funding (the final amount as yet not determined) to each local monitoring committee to carry out its duties. Once a final site is designated, the monitoring committee for that host community will continue serving as the community's representative overseeing the design, construction and operation of a disposal facility. The community will receive an annual benefits and compensation package during the design, construction, and operation phases of the disposal facility.

At the time the local monitoring committees are created, the Authority will establish a statewide review board to hold public hearings within the candidate site communities. The review board will receive comments from citizens, civic leaders and organizations of the candidate communities, and provide the Authority with its own recommendation for a preferred host site.

Each of the candidate sites will undergo 18 months of site characterization to collect environmental data necessary to support license application requirements.

The Authority will consider the reports from the citizen committees and the review board prior to making a recommendation to the Michigan Legislature on a preferred site.

In February 1989, the Authority announced that the St. Clair and Ontonagan candidate areas were excluded from further consideration in the siting process as a result of interpretation of newly developed wetlands data. The decision was made because of the presence, frequency, size, and location 
of wetlands in those areas as defined under the State's Wetlands Protection Act, and as required under the State law establishing siting criteria. The Authority determined that the presence of wetlands in the two candidate areas made it difficult to identify areas sufficiently large to characterize parcels of 1 and within the 2,250-to 4,000-acre range.

Authority officials aiso announced that the Lenawee County candidate area appeared sufficiently large to allow for identification of the three separate candidate sites, as raquired by State law. The Authority indicated, however, that wet? ands information for that area would be further analyzed, along with other criteria applied in the candidate area evaluation phase.

On May 23, 1990, the Michigan Low-Level Radioactive Waste Authority issued a news release announcing that the Riga Township area in Lenawee County, the only remaining siting area under consideration, had been eliminated from further consideration. According to the release, future work "will focus on collection of data that can be utilized in making the determination if, in fact, a site can be found that meets the state siting criteria."

The Michigan Low-Level Radioactive Waste Authority originally identified 81 eligible areas as potentially suitable for a low-level radioactive waste disposal facility. In August 1990, the Authority requested additional funding from the Midwest Compact Commission to evaluate the remaining 78 sites to see if any of them meet the siting criteria. The compact commission turned down the request at that time, but indicated it would appropriate $\$ 400,000$ for additional evaluation contingent on the Authority going to the Michigan Legislature and getting the legislature to change the State's siting criteria. In the meantime, the compact commission suggested the Authority use its existing staff and resources to perform as much site evaluation as possible. Prior to the commission decision, the Authority technical staff had been collecting readily available information on the 78 sites, such as topographic maps and information from other state agencies.

As a result of Michigan eliminating the third of its three candidate 
sites, the State of Washington, which operates the Richland low-level radioactive waste disposal facility, sent a letter to Gov. Blanchard which threatened to deny Michigan generators access to the facility unless the Michigan Legislature revises the State's siting criteria, candidate sites are designated for characterization, or "Michigan provides evidence of good faith actions... [that it is seeking to meet the requirements of the Low-Leve] Radioactive Waste Policy Amendments Act of 1985.']

The States of Nevada and South Carolina, where the Beatty and Barnwell low-level radioactive waste disposal facilities are located, similarly have threatened to deny access to those facilities.

Michigan Authority officials believ the State is in compliance with the Federal milestones, and the Authority plans to continue with its site selection process. Howeve:, Michigan will pursie all avenues necessary to maintain access to the existing disposal sites.

\section{Nebraska--Host State for the Central Compact Region}

Nebraska is the Host State for the Central Interstate Low-Level Radioactive Waste Compact region. Other compact region member States are Arkansas, Kansas, Louisiana, and Oklahoma. Nebraska joined the compact region in 1983 and, in December 1987, was selected as the compact region's first Host state for a regional waste disposal facilit $\because$. The State will host the disposal facility for 30 years or until five million cubic feet of low-level radioactive waste have been disposed of at the facility, whichever comes first. The compact commission selected US Ecology to site, construct, and operate a LLW disposal facility. In 1986 Nebraska enacted the Low-Level Radioactive Waste Disposal Act which assigned the Department of Environmental Control (DEC) responsibility for licensing the facility in accordance with State requirements.

As authorized by Nebraska 1aw, the compact commission collected $\$ 300,000$ from the other compact region member states for distribution as unrestricted Community Improvement Cash Funds and deposited the money with the DEC. In 
1989, the DEC distributed the funds equally to the three potential candidate host areas identified by US Ecology.

State law stiplilates that after three candidate sites are selected, local monitoring committees will be formed in each candidate site. US Ecology provided the State with $\$ 100,000$ for each committee to support its activities during the site characterization process. With the funds, the commilitee could hire staff or contractor support for independent technical review during the siting process, site characterization, and license application review. Once US Ecology identifies the preferred site, that host community's local monitoring committee will receive $\$ 100,000$ annually through the time the disposal site is being developed and operated. These funds will be collected by the disposal facility operator through a fee surcharge assessed on facility users and distributed by the Department of Environmental Control.

State law also requires public participation in the siting process. In response to this requirement, US Ecology sponsored the formation of a 12-member, statewide citizens' advisory committee through the League of Women Voters. The committee provided comments and recommendations regarding the process and criteria for evaluating potential areas for the disposal facility. The committee also reviewed the technical assumptions made by the project management team.

US Ecology also sponsored public workshops at each stage of the siting process both to explain the process and to receive public comments about the criteria being used for area or site evaluation.

In April 1988, US Ecology developed draft siting criteria, which were presented for comment to the citizens' advisory committee and to the public through a series of public workshops. As a result of the committee review and workshops some changes were incorporated into the criteria, particularly considerations such as size and shape of available land parcels to be evaluated, proximity of a proposed site to seasonally populated areas, and presence and proximity of improperly closed boreholes or wells. 
US Ecology screened 21 counties that expressed an interest in being evaluated. This screening used exclusionary and preference criteria to identify areas that are

- Outside a 100-year flood plain and high water and flood areas

- Away from wetrands

- $\quad$ Outside the influence of public water wells

- Two or more miles from geologic faults

- Outside legally dedicated Tands

- Outside the habitats of threatened or endangered species

- Away from National Register and paleontological sites

- $\quad$ Outside areas vith incompatible land uses

- 15 or more miles from population centers over 100,000, and two ir more miles from population centers of 5,000 .

From the initial screening process completed in August 1988 approximately 81 potential areas were identified in 17 of the 21 interested counties. These potential areas comprised about 22 percent of the state.

In September 1988, US Ecology began more indepth evaluations of the 17 counties. The result of this evaluation was identification of 111 potential siting areas with characteristics that appeared acceptable for siting, at this level of screening. The areas comprised 522 square miles in 11 counties, and ranged from half of a square mile to 18 square miles. The following factors were applied to the 17 counties to identify the 111 potential siting areas:

- Groundwater: Depth to groundwater zones, complexity of hydrogeologic conditions, potential surface discharge of groundwater, proximity to major recharge zones, and relationship to all recharge zones

- Geology: Site composition, geologic hazards (e.g., subsidence and slumping), proximity to minerals and resources, ease of characterizing, modeling and monitoring, and low permeability 
- Surface water: Proximity to bodies of water and areas with drainage problems

- Land: Proximity to dedicated lands and facilities or activities that may interfere with required monitoring

- Transportation: Proximity to existing Federal and State highways

- Populations: Proximity to population centers

- Cultural and Paleontological Resources: Proximity to significant archaeological and paleontological sites

- Biological Resources: Proximity to listed threatened or endangered species habitat and sensitive wildlife habitats such as wet 1 ands

- Engineering Feasibility Considerations: Acreage and configuration control and erosion control requirements.

The compact region's siting plan calls for identification of three candidate sites for evaluation. US Ecology decided, with the concurrence of the citizens' advisory committee, to select each of the three candidate sites from different regions of the state in order to reduce the likelihood of encountering a common characteristic that might eliminate all three sites from further consideration. The regions are the North Central Tableland Groundwater Geology Region, the Nebraska Glacial Drift Groundwater Geology Region, and the remaining groundwater geology regions.

In October 1988, US Ecology began evaluating the 111 potential siting areas to identify tracts of at least 320 acres, measuring at least one-half mile by one mile, and held by owners willing to

- Grant an option to purchase the land at a future date

- Renew that option periodically

- Grant access to US Ecology to undertake characterization studies.

Private 1 and agents, representing US Ecology, began visiting candidate sites to identify land owners receptive to selling 1and. In December 1988, US Ecology and its subcontractor began visually assessing the most promising potential sites. General topography, site drainage, and transportation access 
were specifically noted in these visits. Some potential siting areas were dropped at this point in favor of sites in Boyd, Clay, Keith, Kimball, Nemaha, Nuckolls and Webster counties, which were more promising from a hydrogeologic perspective.

In January 1989, US Ecology recommended candidate sites in Boyd, Nuckolls, and Nemaha counties based on geologic, groundwater, surface water, topographic, and environmental resource information.

Following six months of site characterization activities at the three candidate sites, US Ecology announced in December 1989 that the Boyd County site had been chosen as the preferred site for the low-level radioactive waste disposal facility. This selection was based on several conditions:

- Unique geologic conditions that will maximize long-term protection and provide for an effective and highly predictable monitoring system

- A relatively simple geology which allows for modeling and characterizing with a high degree of reliability

- 500 to 1,000 feet of impermeable shale bedrock beneath the site which will provide a sound natural barrier to the aquifer system.

Site characterization activities are ongoing. US Ecology submitted a license application for the Boyd County site to the DEC July 31, 1990. Under the current schedule, US Ecology anticipates submitting a draft environmental impact arialysis and a safety report and holding public hearings by the spring of 1991, and by the fall of 1991 receiving a decision on the license from the DEC.

\section{New York}

New York is an unaffiliated State developing its own low-level radioactive waste disposal facility.

New York decided to develop a State-owned and operated disposal facility to ensure capacity for the State's waste generators. As an initial step 
toward this goal, the State Legislature passed the New York State Low-Level Radioactive Waste Management Act in 1986 which establishes the framework for developing a disposal facility. The legislation created the Low-Level Radioactive Waste Siting Commission and gave it responsibility for selecting one or more sites for a disposal facility and for selecting the dispusal method to be used at the facility. Upon selection of the preferred site(s) and disposal method, the siting commission is to apply for certification from the State Department of Environmental Conservation (DEC). Once this certification is granted, the New York State Energy Research and Development Authority (NYSERDA) will assume responsibility for applying for a license and constructing and operating the disposal facility(s).

Public involvement in the siting process is required by New York State law. The State Low-Level Radioactive Waste Management Act mandates establishment of an advisory committee made up of 13 members appointed by the governor representing academia, industry, government, interest groups, and the general public. Established in 1987, the advisory committee provides advice to the siting commission, as well as to the DEC, NYSERDA, and the Department of Health. The advisory committee is directed by law to review activities related to selection of a site(s) and disposal method(s) certification, and the development of aid to local governments. The advisory committee will continue operating until the DEC certifies the disposal site(s) and method(s), and issues a final environmental impact statement.

Public comments and information received during the candidate area phase of the siting process were used in identifying five potential sites for precharacterization. Sections of the site selection report address the comments provided to the siting commission by local governments and citizens' committees.

New York is an Agreement State with responsibilities to regulate the management of certain radioactive materials, including the disposal of low-level radioactive waste. State law prescribes disposal methods that can be considered and specifies certain factors that should be considered in site selection. State 1 aw excludes the West Valley Nuclear Services facility in 
the western part of the State from consideration.

The siting commission is using a two-phased approach'u site selection. Phase I is site recommendation, and Phase II is detailed site characterization. Phase I is divided into four steps to identify two or three candidate sites for characterization. New York currently is in the finai step of Phase I. These steps are

- $\quad$ Performing a statewide exclusionary screening to eliminate areas from further consideration

- Screening the remaining non-excluded areas to identify the 10 candidate areas most suitable based on weighted criteria

- Evaluating the 10 candidate areas to identify four to eight potential sites

- Performing limited onsite studies of potential sites and selecting at least two candidate sites for detailed site characterization.

In surveying the State for potential sites, the siting commission's site selection plan provided for evaluation of volunteer communities or sites that were offered for consideration to host a disposal facility. These volunteer locations would be assessed using the same exclusionary and preferential criteria as were applied to other sites and areas during the evaluation process. Of five volunteer sites offered by their owners, one is included among the sites now being considered.

Phase I of the siting process began in June 1988, when the siting commission applied the exclusionary criteria that eliminated 30 percent of the State from further consideration. Eliminated were

- Areas immediately above the Long Island aquifer or any primary or principal public watel supply aquifer designated by the DEC and Department of Health

- Towns and cities with an average population density of more than 1,000 persons per square mile

- Federal and State protected lands and Native American reservations. 
In the second step of Phase I, the siting commission applied additional exclusionary criteria and preferential criteria to the portions of New York not previously excluded in order to identify 10 candidate areas. Following application of these criteria, 60 percent of the state, or 30,000 square miles, remained eligible for further consideration.

The additional exclusionary criteria applied at this step included

- Proximity to abandoned mines

- The Western New York Nuclear Service Center in West Valley

- Significant, perennial bodies of surface water.

To the 30,000 square miles remaining eligible following this step, the siting commission applied some 16 additional preferential criteria, including such geologic considerations as soil type, seismicity, distance from public water supplies, aquifers, and gas fields. Demographic and institutional considerations such as population densities and transportation factors were also included. The preferential criteria and associated weighted values had been selected by the siting commission, with assistance from the advisory committee and comments from other interested groups, in August 1988.

Weighted preferential criteria included

- Low seismic hazard

- Presence of geologic units that can accommodate the disposal facilities and retard radionuclide movement

- Distance from active or abandoned gas or oil fields, underground injection wells, underground gas storage and solution mining areas

- Distance from high-yield aquifers

- Distance from significant surface water features that are likely to be sustained by groundwater discharge through the site

- Low population densities

- Proximity to major waste generators

- Climatological considerations. 
Using a predetermined preferability score as a cut-off point, 30 potential candidate areas, ranging in size from 50 to 150 square miles, remained eligible following the application of the criteria. In order to reduce the number of areas to 10 as specified in the New York State Siting Plan, the siting commission applied additional criteria for which data previously had not been included in the computerized screening system. These criteria included the presence of agricultural land and wetlands within the candidate areas, proximity to existing mines, archaeological sites, sources of radiation, and other characteristics such as drainage and subsurface dissolution.

In December 1988, the siting commission announced that 10 potential siting areas across the State remained eligible ror consicieration. The areas range in size from 50 to 150 square miles, comprising about two percerit of the State. The commission held public information meetings in each area of the candidate areas in January 1989. In May, the State legislature appropriated $\$ 50,000$ in financial assistance for each of the 10 candidate areas for use by the respective counties to provide the siting commission additional information that may bear upon the suitability of the potential siting areas.

In January 1989, the siting commission entered the third step of Phase I, to identify four to eight potential disposal sites with a minimum of 200 acres of contiguous 1 and within the 10 candidate areas. Each of the 10 candidate sites was evaluated using a ge-jraphic information system that analyzes grids of 40 acres. At this stage of screening, some criteria evaluated in the earlier stages were reapplied using much more specific data.

Exclusionary criteria at this stage included presence of wetlands and agricultural lands, and proximity to aquifers. Forty-three favorability criteria were applied, including soil characteristics, geology, public water supplies, population densities, climate, precipitation, transportation and socioeconomic factors. Using a criteria weighting system and a predetermined cut-off score, 96 potential sites were identified. To these were added five sites offered for consideration by the property owners. The final application screening using geologic mapping took into account site-specific features, 
such as intersection of the site by a highway or stream and local topography. The minimum site size was also increased to 400 acres to allow more flexibility in facility location arid configuration. This allowed investigators to further reduce the number to 55 .

Having applied the criteria and data available for geologic mapping, the siting commission turned to visual inspections, aerial photographs, and published information to identify such features as $0 i 1$ and gas wells, erosion factors, and agricultural activities that would affect disposal site performance modeling. Applying the professionai judgment of specialists in a range of technical disciplines, the siting commission narrowed consideration to 19 locations.

At this point, the siting commission reapplied on a site-specific basis the criteria and weighted values listed in the site selection plan, and applied 17 critzria such as erosion, drainage, noise, and aesthetic factors that could only be obtained on a site-specific basis.

In September 1989, the siting commission announced five potential sites for a disposal facility: two in Cortland County (Taylor Central, 473 acres; and Taylor North, 686 acres), and three in Allegany County (West Almond, 918 acres; Canaedea, 1039 acres; and Allen, 780 acres).

Since selection of the five potential sites, siting commission survey teams have been physically blocked by opponents from gaining access to the potential sites for any precharacterization work. In some instances, survey personnel have required police escorts from a site after protestors surrounded the officials and would not allow them to leave. Opponents of the sites have handcuffed themselves to bridges attempting to block access to a site, and in one instance, minor injuries occurred during a confrontation between state police and protestors.

Following the incident in which injuries occurred, Governor Cuomo issued a statement which said, in part: "...I think it is reasonable for the State siting commission temporarily to refrain from any further onsite 
precharacterization work at the candidate sites in Cortland and Allegany counties, without suspending the site and disposal method selection process. What I am suggesting is that until I have had the opportunity to discuss this matter further with State legislators and local citizens, the commission should concentrate its efforts on other more productive activities."

Pending the outcome of these discussions, the siting commission and its staff are continuing to examine existing data without attempting to gain access to the sites. Work also is continuing on the selection and description of disposal methods.

As of the end of July, there was no onsite precharacterization work planned at the five candidate site areas, and the only siting work under way was a review of the previously completed technical studies of the candidate site areas.

In June Governor Cuomo held meetings with local citizens and state legislators from the potential site areas. As a result of those meetings, the Governor signed into law a low-level radioactive waste bill that has three major provisions.

1. The siting commission will identify a preferred method of disposing of low-level radioactive waste and put the proposal through a public hearing process before the site selection process is restarted. The siting commission will evaluate candidate site areas against the "preferred method," and then will recommend a final site to the Department of Environmental Conservation.

2. The law revised the makeup of the 13-member citizens' advisory committee by replacing voting members from State agencies with citizens representing specific professions and geographic areas.

3. The bill expands the siting commission from five to seven members with the additional representatives from a citizens' not-forprofit environmental group and a sociologist. 
The siting commission chairman opened consideration of the West Valley Nuclear Services facility as a potential low-level radioactive waste facility site. The commissioners agreed that he should collect preliminary data available on the site and to seek an opinion from the town of Ashford's elected officials about using the West Valley site as a low-level radioactive waste disposal facility. The legislature would have to rescind by amendment the law excluding West valley from consideration. In authorizing the review of West Valley, the siting commission stipulated the facility must undergo the same technical evaluations as the other areas of the State. A decision to reconsider West Valley could be made only by the legislature.

\section{North Carolina-- Host State for the Southeast Compact Region}

In 1983, North Carolina joined the Southeast Interstate Low-Leve1 Radioactive Waste Management Compact region, which also includes Alabama, Floricia, Georgia, Mississippi, South Carolina, Tennessee, and Virginia. North Carolina was designated by the compact commission to host the second regional disposa? facility following closure of the operating disposal facility in Barriwel1, South Carolina, December 31, 1992. The North Carolina facility is to remain open for 20 years or until the facility has received 32 million cubic feet of waste.

The Low-Level Radioactive Waste Management Authority (the Authority), which was established by 1 aw in 1987, is charged with siting, building, leasing or operating, and closing the disposal facility. The Authority is composed of 15 citizens who are not elected officials or employees of State agencies. The governor, lieutenant governor and speaker of the house each appointed five members to the Authority.

The Authority is charged with establishing procedures and criteria for evaluating alternative locations for the facility, which is consistent with the rules of the North Carolina Radiation Protection Commission. The General Statutes 1 ist a number of factors that must be considered in screening the State for suitable disposal sites. 
The Authority compiled and evaluated Federal and State regulations to identify those that are applicable to statewide screening, and those that were applicable to area or site-specific screening. Regulations were further subdivided into those that identified exclusionary criteria and those that identified suitability ci iteria.

The selection of a preferred site for a disposal facility in North Carolina is based on the application of a phased screening process conducted by the Authority's technical contractors. The Authority entered a contract with Ebasco Services Inc. in JuTy 1988 to perform the first two siting phases: identification of "potentially suitable areas" (Phase I), and identification of a smaller number of "candidate areas" (Phase II).

In an effort parallel to the screening process, the Authority encouraged volunteer host sites within any areas of the State that were not specifically excluded by State or Federal regulations. Communities were encouraged to express their interest in hosting the facility through their local elected officials. Volunteer communities would be evaluated on technical merit and ability to be licensed and would be included in the overall siting process. The invitation did not result in any volunteer host sites.

The Authority conducted public hearings prior to adopting the siting procedures and criteria. Several of the comments from the public resulted in amendments to the guidelines. Examples are the addition of proximity to national wildlife refuges, fish hatcheries and natural landmarks as features to be avoided, and local land uses including "land adjacent to nuclear power plarits" as favorable characteristics. Changes to the siting criteria resulting from the public hearings are explained in the report, Summary of Comments from March 21-23, 1988, Public Hearings and Recommended Responses, April 1988.

In Phase 1, Ebasco applied a number of exclusionary criteria reflecting the technical feasibility, potential to meet licensing requirements, and factors related to public acceptance. Areas with the following characteristics were excluded from further consideration: 
- Flood-prone coastal areas: Areas likely to flood in the storm surge created by a severe (Class 5 ) hurricane

- Flood plains of rivers and swamps: Areas where 100 percent of the area floods and swamps greater than 500 acres in size

- Public drinking water supplies: Areas with municipal water wells, plus a 1,000 -foot radius

- High water table: Areas where 100 percent of the area has a water table at six feet or less

- Population density: The 1987 boundaries of municipalities, census-designated urban areas, and census-designated unincorporated towns, plus a two-kilometer buffer zone

- Lakes and scenic rivers: Lakes greater than 500 acres in size, and officially designated scenic rivers

- National parks, national forests, state parks, itdte forests, Indian reservations, military reservations, and Federal wildi ife refuges.

These exclusionary criteria eliminated a large portion of the state from consideration, particularly in the coastal plain region and heavily populated regions. The survey identified 38 percent of North Carolina (20,446 square miles or almost 13.1 million acres) as potentially suitable at this level of screening. The Authority accepted Ebasco's Phase I recommendations on potentially suitable areas. Areas not excluded in this phase were defined as potentially suitable areas.

Following the statewide screening, Ebasco began Phase II. Additional exclusionary criteria were applied to the potentially suitable areas from Phase 1. This screening process culminated early in 1989, when Ebasco recommended candidate areas to the Authority comprising 9.5 percent of the State's land (about 5,054 square miles). The Authority accepted the recommendation and announced selection of the candidate areas on March 20 , 1989. During Phase II, land with the following characteristics was removed from consideration:

- Areas with swamps, wetlands, lakes, ponds, and fresh water upland bogs 
- Areas where more than 90 percent of the land area is subject to periodic flooding

- Areas with known mineral exploitation

- Areas prone to the development of sinkholes

- Areas less than two miles from municipal water wells

- Areas less than two miles from the North Carolina State boundary

- Areas with population densities greater than 500 persons per square mile.

Ebasco's submission of candidate areas was to be its final contractual obligation with the Authority. However, contract negotiations were still under way between the Authority and Chem-Nuclear Systems Inc. to site, design, build, operate, and close a disposal facility. To avoid interrupting siting work during the negotiations, the Ebasco contract was extended into Phase III. In this phase Ebasco applied a set of exclusionary and suitability criteria available at this level of screening in order to identify suitable areas from within the candidate areas. These criteria included

- Areas of at least 150 contiguous acres, all of which met the statewide exclusionary and suitability screening criteria

- The slope within an area's boundaries generally should not exceed two degrees

- Areas could not have any churches, hospitals, cemeteries, schools, or prisons

- Areas must have virtually no shallow groundwater, and no perennial streams or swamps.

The suitable areas Ebasco identified included 116 tracts of 1 and ranging from 700 to 2000 acres, mostly within the borders of single counties. One of the tracts which the Authority would accept for further study straddled the county line separating Wake and Chatham counties.

As Ebasco was completing the identification of the suitable areas, the Authority completed negotiations and entered into a contract with Chem-Nuclear. The company assumed the siting work, reexamining and verifying 
Ebasco's process for identifying the 116 suitable areas and the results of the screening. Chem-Nuclear then continued the screening process by applying additional exciusionary and suitability criteria. These included

- Size of the potential site: A minimum site size and buffer of about 500 acres

- Buffer zone characteristics: A minimum 1,000 feet from the edge of the storage cells' projected location; no perennial streams, swamps, or 100-year floodplains; no severe topography such as ravines, cliffs, bluffs; no indication of shallow groundwater in the buffer or at the boundary

- Environmental factors relating to water quality: No direct discharge into streams classified as outstanding resource waters.

On November 8, 1989, Chem-Nuclear recommended four favorable site areas to the Authority for precharacterization. The recommended site areas were a 2,000-acre tract in Richmond County, a more than 1,000-acre tract in Rowan County, a less than 1,000-acre tract in Union County, and a nearly 750-acre tract straddling the Wake and Chatham county lines. The Authority accepted Chem-Nuclear's recommendation and authorized precharacterization studies on the four site areas. The precharacterization of the four site areas involved

- Conducting site-specific field studies to collect data on hydrological and geological factors of the sites, such as their ability to be readily modeled

- Reviewing environmental and public health factors

- Reviewing seismic information

- Collecting more detailed natural, cultural, and socioecornmic information

- Evaluating topographical, ecological, archaeological, recreational, cultural, and historic features

- Evaluating site accessibility.

The Authority and Chem-Nuclear conducted public meetings in each of the counties containing the favorable site areas and received additional technical information and public comments. In February 1990, Chem-Nuclear recommended that the Richmond County and Wake/Chatham County areas be considered for 
formal characterization, and that the two other areas be el iminated. The company found that each of the two sites had features favoralle for siting:

- Large enough to accommodate a disposal site of up to 500 acres

- Potential buffer zone areas with no perennial streams

- Groundwater depths greater than "feet

- Slopes of less than 2 percent

- No watersheds or outstanding water resources

- Population densities less than 500 persons per square mile

- Shapes amienable to locating disposal cells, suiport buildings and buffer zones.

Chem-Nuclear recommended elimination of the other two areas because it believed that surface and groundwater characteristics would likely inake the areas difficult to license. These characteristics included perennial streams in the Rowan and Union County sites that indicate shailow groundwater. The Union county area also included a watershed that was scheduled to be reclassified into a more restrictive category of land use. On March 10, 1990, the Authority voted to el iminate the Rowan and Union County areas from further consideration, and on April 30 voted to authorize characterization of the Richmond and Wake/Chatham County areas.

After announcement by the Authority of the sites to be characterized, State law provides for establishment of site designation review committees for each area, with membership appointed by the respective county boards of commissioners. The committees will advise the county commissioners on all aspects of the site selection process. Each committee will be ailocated $\$ 50,000$ (or a total of $\$ 75,000$ if two counties are involved). Following characterization, the committee in the area selected as the favored site will remain active during the operational life of the disposal facility.

After each of the areas is ciaracterized, State law requires the Authority to hold public meetings in each of the counties. Following consideration of comments received at the meetings, the Authority expects to 
select a preferred site in 1992 .

Following selection of the preferred site, State law requires the Authority to develop a finaricial benefits package in cooperation with community leaders, the site designation review committee, and public interest groups.

Boards of county commissioners for each of the three counties in which the Richmond and Wake/Chatham favorable sites are located appointed 11-member site designation review committees to review the site-specific characterization plans prepared by Chen-Nuclear Systems. Each of the review committees submitted its comments on the characterization plans to the Division of Radiation Protection.

\section{Texas}

Texas is an unaffiliated state developing its own low-level radioactive waste disposal facility. Texas enacted the State Low-Level Radioactive Waste Disposal Authority Act in 1982 to implement the requirements of the Federal Low-Level Radioactive Waste Policy Act of 1980. The State law established the Authority and gave it responsibility for siting and operating a disposal facility. The law maridates public involvement in the siting process and impact assistance funding for the host community of the facility.

State law requires that two of the six voting members of the Authority board of directors be appointed by the governor to represent the general public. Once a preferred site is selected, the law requires the governor to appoint a representative of the general public (a resident of the disposal facility host county) as a voting Authority board member.

The criteria used to guide the site selection process were developed by the Authority's technical staff. They incorporate the statutory site solection criteria contained in Texas revised civil statutes, regulations of the Texas Department of Health's Bureau of Radiation Control, and applicable Federal regulations. 
When the siting process began in 1982, the Authority selected a five-member citizens' advisory panel made up of officials representing various geographic areas of the State to review siting data and provide public comment and oversight. A major contribution of the advisory panel was its assistance in developing the uniform site ranking process based on environmental, engineering, and economic concerns. This ranking process was used by the Authority throughout the siting process.

The site selection process originally consisted of three site screening phases. The objective of the first phase, begun in 1982, was to identify regions of the Stite likely to yield areas with characteristics suitable for a disposal site. Unlike several of the other States that began their screening with application of a uniform set of exclusionary criteria, Texas was able to begin its process with more specific regional evaluations because of the State's large number of distinctive regions, each with different characterisicics potentially suitable for low-level radioactive waste disposal. In the second phase, the eligible regions were further evaluated to identify specific potentially suitable sites. In the third phase, precharacterization studies were performed on several sites identified in the second phase. In 1984, during implementation of the process, Texas law was amended to require reapplication of the screening phases to State-owned land.

In the first phase of screening, regional areas were identified that did not have

- 100-year floodplains, wetlands, and coastal high hazard zones

- Shallow water tables

- Recharge zones of the major or minor Texas aquifers

- Projected future population growth

- Seismic activity or faulting

- National, Federal, or State parks or wildlife management areas

- Long distances to State highways 
- Permeable soil

- Varying geologic conditions that could make a site difficult to characterize and model.

Through the statewide screening process, the Authority identified 15 large areas likely to contain suitable sites for a disposal facility. After examining each of the areas in more detai1, particularly for favorable geologic and soil conditions, the Authority selected eight for additional evaluation in the second phase of the siting process.

The areas selected were Hudspeth County, the Nueces Plains, the Black Prairie, the North-Central Prairies, the Western Cross Timbers, the Abilene-Haskell Plains, the Red Bed Plains, and the Northern Black Prairie. Of these, the Authority determined that the Nueces Plains, the Red Bed Plains and Hudspeth County possessed the most favorable characteristics, particularly groundwater levels, low population densities and hydrometeorogical factors.

In May 1983, the Authority began Phase II evaluations of the eight regional areas to reduce the amount of 1 and in each subject to further evaluation. The Authority screened each region with respect to more specific geological and transportation factors. Concurrently, efforts were made to locate land within the favorable areas that might be available for purchase because the Authority does not have power of eminent domain.

From the remaining area, the Authority identified approximately 280 potential sites of at least 250 acres each. Site identification was the result of quantitative application of a number of factors: amount of contiguous area; current land uses; surface drainage and topography; groundwater discharges; surface water resources; demographic, cultural, and recreational features.

Through aerial and field reconnaissance surveys, and validation of map information, the Authority narrowed the possible sites to 57 . Of these, the Authority considered 26 in the Nueces P1ans, 14 in Red Bed Plains, and two in Hudspeth County to have the most favorable characteristics for low-level 
radioactive waste disposal. Except for the sites in Hudspeth County, which were owned by the University of Texas, each of the more favorable sites was privateiy owned.

Dames and Moore, Inc., a contractor supporting the Authority in the site selection process, ranked each of the 57 potential sites with respect to environmental, engineering, and economic factors. Environmental factors included geology; groundwater; hydrometeorology; current 1 and use; land use potential; demographic, cultural, archaeological, and recreational factors. Engineering and economic factors included transportation access, operating costs, site engineering, surface water management, land costs, land availability, and availability of support services. The contractor assigned weighted values to the criteria, evaluated each site with respect to the criteria, and recommended 25 sites to the quthority for further consideration. After further evaluation of the 25 sites, four of the sites potentially available for purchase were recommended to the Authority for continued evaluation.

Upon examination of specific circumstances associated with each site, a11 but two were eliminated from consideration for site characterization. In February 1985, the Authority staff recommended to the Authority Board that two sites in the Nueces Plains (in iicMullen and Dimmit Counties) be considered as candidates for characterization as preferred sites.

About the same time, the Texas Low-Level Radioactive Waste Disposal Authority Act was amended to require additional site selection studies of State-owned land. If suitable State-owned sites could be found, the Authority was to give preference to those sites over equally suitable privately held sites. The amendments also prohibited selection of a site within 20 miles upstream of certain reservoirs, a criteria that eliminated the McMullen and Dimmit County sites. Following enactment of the amendments, the Authority Board of Directors tabled the staff recommendation of the two sites and directed the staff to begin screening State-owned land.

With the cooperation of the Texas General Land Office and the University 
of Texas System, the Authority identified all State-owned 1 and and began the siting process over again, implementing each of the evaluation phases. The first phase of exclusionary and preferential screening reduced the amount of land potentially eligible from 2.9 million acres in 172 counties to 667,000 acres in 10 counties. In subsequent screening steps, the Authority, by June 1985, had identified seven new State-owned sites for further onsite evaluation. To these were added the two university-owned sites in Hudspeth county that had been identified in the previous statewide study.

of the seven new potential candidate sites, there were three in Hudspeth County (including the Fort Hancock site), two in Culberson County, one in Loving County, and one in Ward County. Further evaluation suggested the presence of uniform geologic formations underlying the Fort Hancock site and a culberson site, a favorable feature for siting. The other two Hildspeth County sites revealed presence of bedrock and groundwater protection characteristics, also favorable. The evaluation also revealed the possibility of shallow groundwater in one of the Culberson County sites, and unstable sands and proximity to gas and oil fields at the Loving and Ward County sites.

In August 1985, the Authority decided that the two Hudspeth County sites identified in the original site screening, the Fort Hancock site, and the two sites in Culberson County should be evaluated as potential sites for further study. In December, the Authority entered into a contract with the University of Texas Bureau of Economic Geology for that organization to perform extensive onsite evaluations of the five sites, in conjunction with Texas A\&M University, the University of Texas at El Paso, and Texas Tech.

The onsite investigation showed a potential for underground collapse, a high degree of faulting, and perched water tables at both Culberson County sites. One of the original Hudspeth County sites was elimiriated because of its potential for large flood flows in an adjacent arroyo, and because of the potential for recharge to the groundwater from fractured rock teneath the site. This left the Fort Hancock site and one Hudspeth County site for consideration as preferred sites. 
In early 1987, the Authority was prepared to name the Fort Hancock site as the preferred site, but the selection was delayed when EI Paso County filed suit against the Authority in E1 Paso District Court. The suit contended that the evaluation of the siting criteria had been inadequate. E1 Paso received a temporary injunction in the District Court, but the injunction was overturned upon appeal in the State Court of Appeals because the site had not yet been selected as the preferred site. The Appellate Court's ruling was upheld by the Texas Supreme court.

Following the Supreme Court decision in July 1988, the Authority began further analysis of the Fort Hancock site, completing the work in August 1989. The studies, carried out under contracts with the same universities listed above, indicated that the site is sultable for a low-level radioactive waste disposal facility and that it would likely meet licensing requirements.

During the 14-month onsite study, scientists determined that the site was on a plain underlain by more than 400 feet of mixed clay, silt, and sand, and that the water table was about 500 feet below the surface. Scientists determined there is no recharge to the groundwater at the site. Also, underground geological barriers separate water under the site from the Rio Grande River. Meteorologists discerned that the climate for the site area has been stable for at least 150 years and is expected to remain that way for centuries. The maximum rainfall expected once in 100 years is four inches in a 24-hour period. The sparse rainfall and excellent drainage limit the potential for surface flooding. Nearby faults are relatively inactive, there are no endangered species of $p l a n t s$ or animals found on the site, nor are there any archaeologically significant ruins on the site.

In November 1989, the Authority designated Fort Hancock as the preferred site for a low-level radioactive waste disposal facility. The El Paso County suit was reinstated in early 1990, contending that the Fort Hancock site is flawed, the site selection process is flawed, and that the Authority did not follow the letter of the law in the site selection process.

The Authority, in return for the county's agreeing to seek an early 
court date (then set for April 1990), agreed to postpone completing technical site studies, filing a license application with the Texas Department of Health for a disposal facility, and holding pulitis hearings until the trial.

In February, the Authority made disposal facility design changes during the preliminary phase of the site design process. Because of the design changes, El Paso officials contended that they would need additional time to prepare their case for court. The court granted a continuance until August 13, 1990. The court's action terminated the Authority's agreement with El Paso County to postpone the completion of site evaluations and preparation of a license application in exchange for agreement to set an early court date. The Authority believes that the trial delay has had a significant effect on the schedule for submission of the license application, license approval, and facility construction and operation deadlines. The Authority is now evaluating these adjustments to the process.

Texas law requires that a citizens' advisory board be established within 30 days of the start of construction of the facility. Committee members will be nominated by elected officials of the host county and appointed by the Authority Board of Directors. The committee's responsibilities will include independent monitoring of disposal site activities, and the development of recommendations for allocation of impact assistance (10 percent of the facility's gross revenues) to county political subdivisions.

Because of the court case, the Authority has not pursued any license application work.

\section{Illinois--Host State for the Central Midwest Compact Region}

The Central Midwest Interstate Low-Level Radioactive Waste Compact region is cumposed of Illinois and Kentucky. Compact legislation stipulates that no compact State producing less than 10 percent of the region's waste may be designated to host a disposal facility. As the major producer of low-level radioactive waste in the compact region, Illinois was designated the compact region's Host State for a disposal facility. 
The amended Illinois Low-Level Radioactive Waste Management Act of 1983 assigns responsibility to the Illinois Department of Nuclear Safety (IDNS) for conducting siting studies; licensing; and selecting a contractor to design, construct, operate, and close the disposal facility.

IDNS chose to carry out its obligations in a slightly different manner than the Host States mentioned above. The siting approach taken by 111 inois emphasizes community awareness and involvement. For example:

- Illinois developed an economic benefits and impact mitigation package for communities hosting alternative sites. Through this package, IDNS and the compact commission have distributed over $\$ 1.9$ million in grants to two potential host communities: the town of Martinsville in Clark County for the Martinsville site, and Wayne County for the Geff site. Certain funds are unrestricted, while other funds must be used by the potential host communities to conduct independent technical studies or evaluations of the impacts of hosting a disposal facility.

- In addition to community financial support through grants, IDNS has carried out an extensive public participation program, which includes encouraging the formation of state and local citizens' advisory groups, conducting hundreds of informational meetings and at least four public hearings.

While the public hearings are required by law to be held before identifying alternatives sites, establishing the advisory groups and holding informational meetings were initiated by IONS. The advisory groups provided IDNS with input from the generators, exvironmental groups, the local comunities, and the general public. The informational meetings, some 487 in all (397 of these in Clark and Wayne counties), were used to provide citizens with information about the siting process and to receive comments from the public. 
The site selection process is guided by criteria established in Illinois statutory and regulatory requirements. Under Illinois law, any site selected for a disposal facility must have the approval of the affected unit of government. A municipality has jurisdiction if a potential site is within 1.5 miles of the municipality's borders; the county government has jurisdiction if the site is farther than 1.5 miles from the municipality's borders.

To filfill its mandate to establish a disposal facility, IDNS

- Identified counties interested in hosting a disposal facility

- Evaluated identified counties by applying exclusionary and favorability factors

- Identified potential candidate areas within the identified counties

- Selected potential candidate areas and performed a reconnaissance of these areas

- Selected candidate areas from among the potential candidate areas for more detailed reconnaissance and drilling

- Selected four alternative sites for detailed investigation and evaluation

- Characterized two sites (physical testing and data gathering have been completed, but the findings have not been published as of the completion of this report).

Upon completion of all necessary studies, the director of IDNS will recommend a site to a siting commission which was established in the summer of 1990. The siting commission will then select the facility site.

In May 1987, IDNS contracted with Battelle Memorial Institute to act as an agent for IDNS to conduct a study of the State and eventually recommend at least two alternative sites for a disposal facility to IDNS. The selection process was designed and implemented to offer all communities in 111 inois the opportunity to be considered for hosting the disposal facility if favorabie. interest and suitable geological conditions were present in their areas. 
By late summer of 1987,21 counties had expressed interest in hosting the facility. In cooperation with the Illinois State Geological Survey and the Illinois State Water Survey, IDNS applied a series of exclusionary criteria to those counties to identify potential candidate areas within the counties. The exclusionary factors eliminated areas with potential for significant earthquake activity, areas within a 100-year flood plain, designated Federal and State protected lands, and areas prone to subsidence and 1 andslides. The presence of any one exclusionary factor eliminated a given land unit from consideration.

IDNS next evaluated potential candidate areas using 18 favorability factors. These factors, if present in an area, indicated an increased probability of identifying suitable sites. The factors were broken into two categories: seven performance-related and 11 nonperformance-related factors.

Performance-related factors represented characteristics that provided assurance that a site's geology and hydrology would help prevent or retard the movement of radionuclides in environmental pathways. These factors include (a) areas of low soil permeability, (b) areas of simple geologic structure, (c) areas far from surface water supplies, (d) areas without high-yield groundwater aquifers, (e) areas without shallow aquifers, ( $f$ ) areas with low erosion, and $(g)$ areas without surficial sand and gravel deposits.

Nonperformance-related factors were those that would not directiy affect overall performance of a disposal facility, but which would have an impact on its siting. Examples include (a) prime farmland, (b) areas with archaeological, historical, or cultural sites, (c) areas that may experience future growth, and (d) areas with critical habitats of endangered or important species.

Through this process, IDNS identified 69 potential candidate areas in 17 counties for further evaluation. Four of the original 21 counties were eliminated for technical reasons.

IDNS next performed reconnaissance of the potentiai candidate areas, 
with the goal of identifying several candidate areas. Each area would be about four square miles to provide flexibility in selecting optimal 1,000-acre tracts. The disposal facility would occupy about 300 acres, with the remainder serving as a bufter zone.

Because of adverse public reaction, in January and February 1988 'inz remaining counties notified IDNS that they were no longer interested in being considered. This turnabout occurred as the siting efforts of IDNS became more widely publicized. This publicity generated public opposition, and opponents urged elected officials to withdraw expressions of interest. However, in February the city of Martinsville and five weeks later Wayne County (not one of the original 21 counties) requested chat IDNS attempt to identify a site location within their respective areas. One additional county was also evaluated and eliminated from consideration.

During candidate area reconnaissance and drilling, additional factors were studied. Reconnaissance involved verifying information already collected as well as gathering data from local government sources and State agencies such as the 117 inois State Water Survey and State Geological Survey. IDNS also obtained descriptive information on economic resources, relief, drainage, wetlands, transportation, physical developments, and settlement patterns in each candidate area.

From reconnaissance within Martinsville township and Wayne County, IDNS identified six candidate areas. Following identification of the six areas, IDNS began an evaiuation to select four alternative sites, two of which would eventually undergo detailed characterization. This work involved

- Conducting visual surveys of the areas to verify the results of prior siting steps and to determine the existence of any previously unspecified features

- Obtaining aerial photographs to study topographic features, land use, and demographic patterns

- Drilling boreholes to determine the physical nature of the soil and bedrock 
- Obtaining information from local sources that might be relevant to the siting of a disposal facility.

In March 1988, IDNS selected the Martinsville Alternative Site, located north of the city in Clark County, for the detailed characterization process. In June 1988, IDNS then selected the Geff Alternative Site in Wayne County for characterization. Finally, in August IDNS selected two additional alternatives sites, one in Wayne County and one south of Martinsville in Martinsville and Orange townships.

In May 1988, IDNS announced the selection of Westinghouse Electric Corporation as the disposal facility developer/contractor. Twelve months later, during Phase II contract negotiations, IDNS and Westinghouse were unable to agree on requirements concerning facility ownership, financing, and liability. As a result, IDNS began discussions with another prospective site operator, and in July 1989, contracted with Chem-Nuclear Systems, Inc., to be facility developer/operator.

In September and early October 1989, IDNS held public workshops to report the results of its environmental, geological, and hydrological studies, and to discuss the results of the site characterization work. To satisfy concerns about the site selection process expressed by the public after the workshops, Governor James Thompson directed IDNS to reorganize its procedure for selecting a disposal site. Two weeks later, the Illinois Senate voted to investigate the siting process.

In early 1990, Wayne County facility opponents were successful in having an advisory referendum placed on a March 1990 primary ballot. The referendum basically stated that Wayne County did not want a LLW facility sited in the county. Sixty-eight percent of those going to the polls voted for the referendum. In April 1990, as a result of that expression of opposition to the disposal facility by voters, the county commissioners passed a resolution essentially stating that if IDNS asked the county to host a disposal facility, the county commission would turn down the request. However, the county commission vote in April did not preclude IDNS from continuing 
characterization work at the site.

In the summer of 1990 the Illirois legislature appointed a three-person siting commission made up of a former Illinois Supreme Court justice, a University of Illinois civil engineering professor, and a member of the Sierra club. The commission was to review the site selection process and, if nominated by the director of IDNS, determine whether the Martinsville Alternative Site meets the requirements established in State 1 aw and regulations. Because of the vote of the Wayne County commissioners, the alternative site in that county will not be presented by IDNS for consideration at the siting commission proceedings. The siting commission review will occur early in 1991 after IDNS completes its studies and reports on the Martinsvilie Alternative Site.

\section{CONCLUSION}

Host States have chosen many different paths in approaching site selection for LLW disposal facilities to fulfill their responsibilities under the Low-Level Radioactive Waste Policy Act of 1985. These unique approaches have been developed in response to the specific technical, economic, and political circumstances of each Host State.

It is apparent that the technical and economic aspects of the various site selection processes are similar. What stands out as the primary difference is the political/public response processes which are established at the beginning and which continue to evolve throughout the site selection process. When public opposition develops to a sufficient degree, most states have responded by significantly changing at. least some aspects of the site selection process, such as examining additional technical and social considerations; reevaluating and reorganizing the site selection responsibilities; amending the controlling state legislation; and slowing down, stopping, or restarting site selection activities.

Whether any of these approaches is ultimately successful in achieving the goals of the Act remains to be seen. However, Host States and other 
States approaching a site selection process can iearn from these experiences and incorporate the positive aspects into their own programs. One of the lessons that can be drawn from these experiences is that political and public processes will exert a powerful influence on the site selection process at virtually every stage. Often this influence is positive, and siting processes have improved because of it. Agencies with the responsibility for siting a LLW disposal facility must take into consideration this influence and respond in a positive manner, whilo designing their processes to be flexible enough to accommodate the pressure.

As U.S. Nuclear Regulatory Commissioner Forrest Remick has said, "The surest way to enhance the risk of failure is to provide no workable alternative to a narrowly defined path to success." The mirror of this statement is equally apt: "The surest way to achieve goals is to provide workable alternatives along a well-defined path to success." 


\section{REFERENCES}

1. Code of Federal Regulations, 10 CFR 61, "Licensing Requirements for Land Disposal of Radioactive Wastes, "Office of the Federal Register, January 1990. 

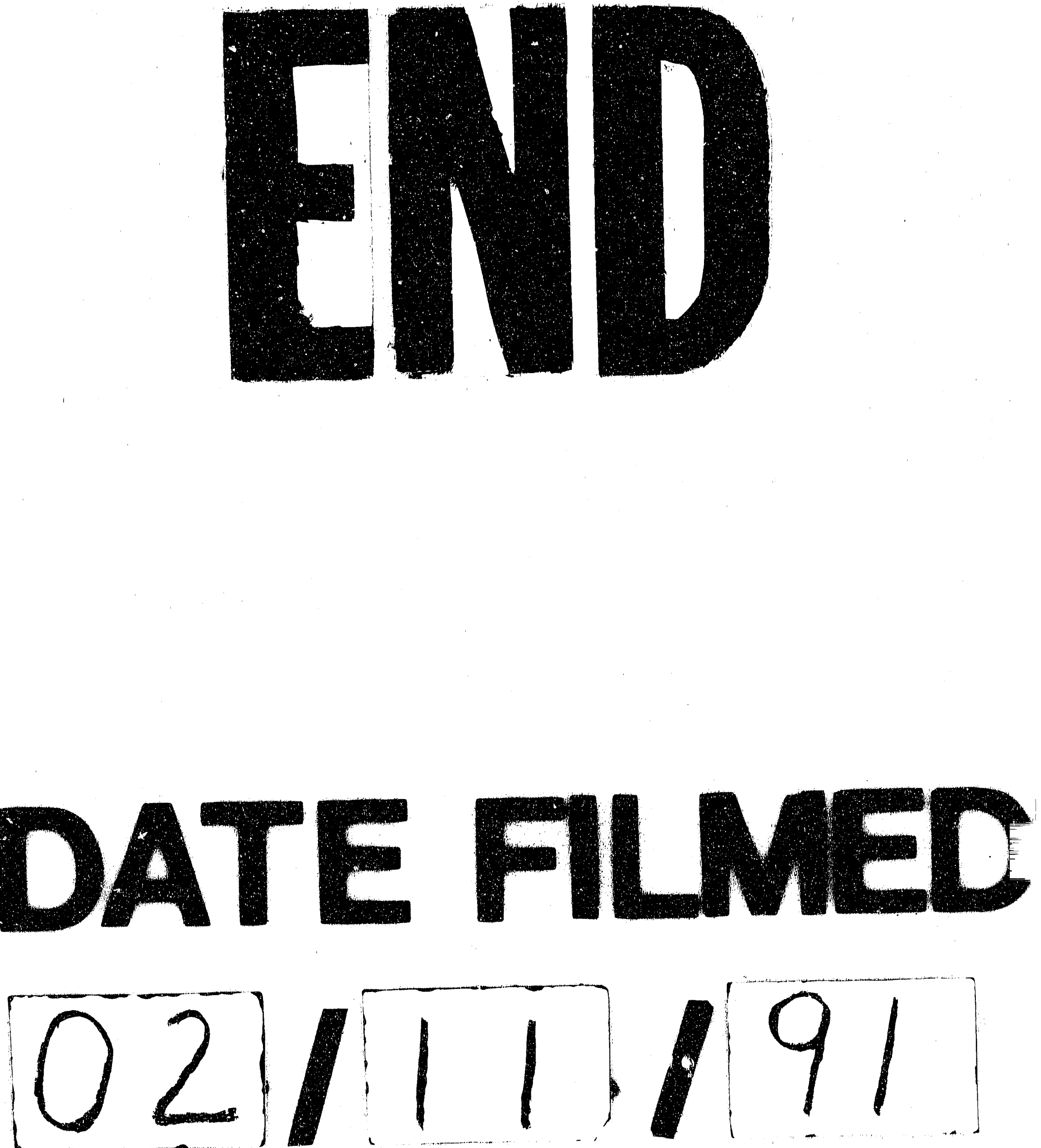
